\title{
Effects of water temperature and pikeperch (Sander lucioperca) abundance on the stock-recruitment relationship of Eurasian perch (Perca fluviatilis) in the northern Baltic Sea
}

\author{
Eevi Kokkonen $(\mathbb{D} \cdot$ - Outi Heikinheimo $\mathbb{D} \cdot$ Zeynep Pekcan-Hekim $(\mathbb{D} \cdot$ \\ Anssi Vainikka 1 (D)
}

Received: 17 October 2018/Revised: 22 May 2019/Accepted: 22 June 2019/Published online: 9 July 2019

(C) The Author(s) 2019

\begin{abstract}
How spawning stock size, environmental conditions and recruitment relate to each other is an essential question in understanding population dynamics of exploited fish stocks. We estimated the recruitment of Eurasian perch (Perca fluviatilis), one of the most important species in coastal fisheries in northern Baltic Sea, and examined the factors that determine perch recruitment success. We hypothesized that perch spawning population biomass and summer water temperature would increase perch recruitment, with potential density dependence, while the effect of the population size of pikeperch (Sander lucioperca) would be negative. Different forms of general stockrecruitment functions, with and without density dependence, and with and without water temperature
\end{abstract}

Handling editor: Grethe Robertsen

Electronic supplementary material The online version of this article (https://doi.org/10.1007/s10750-019-04008-z) contains supplementary material, which is available to authorized users.

\section{E. Kokkonen $(\bowtie)$}

Department of Environmental and Biological Sciences, University of Eastern Finland, P.O. Box 1627,

70211 Kuopio, Finland

e-mail: eevi.kokkonen@uef.fi

\section{O. Heikinheimo}

Natural Resources Institute Finland (Luke), Latokartanonkaari 9, P.O. Box 2, 00791 Helsinki, Finland e-mail: outi.heikinheimo@luke.fi and pikeperch population size as environmental factors were fitted to long-term (1981-2014) stock assessment data of perch and pikeperch in the Archipelago Sea, southwestern coast of Finland. Perch spawning stock biomass (ages 5-14), water temperature in June-July and pikeperch stock size (ages $\geq 1$ ) at spawning year best explained variation in perch recruitment. The results supported the predictions: perch recruitment increased with spawning stock in density-dependent manner, pikeperch effect on perch recruitment was negative and summer temperature effect was positive suggesting environmentally affected competitive interaction between these two percids.

Keywords Spawning stock $\cdot$ Recruitment $\cdot$ Fisheries management $\cdot$ Competition $\cdot$ Predation $\cdot$ Percidae

\footnotetext{
Z. Pekcan-Hekim

Institute of Coastal Research, Swedish University of Agricultural Sciences, Öregrund, Sweden

e-mail: zeynep.pekcan.hekim@slu.se

A. Vainikka

Department of Environmental and Biological Sciences,

University of Eastern Finland, P.O. Box 111,

80101 Joensuu, Finland

e-mail: anssi.vainikka@uef.fi
} 


\section{Introduction}

Large fluctuations in the recruitment success are characteristic to many percids (Neuman et al., 1996) which creates an inherent challenge for their fisheries. Eurasian perch (Perca fluviatilis L.), hereafter perch, is a widely distributed, generalist freshwater species found in diverse aquatic environments including coastal brackish waters. Both perch and the confamilial pikeperch (Sander lucioperca L.) favour sheltered areas over open pelagic surfaces in the Baltic Sea (Veneranta et al., 2011; Kallasvuo et al., 2017), and both species spawn in inner bay areas characterized by low salinity, high temperature and significant vegetation cover (Kallasvuo et al., 2017). Recruitment of perch and pikeperch in boreal environments is dependent on the warm summer temperatures in the first year of their life, because fast growth and large size after the first summer improve their chances of survival through the critical first winter (Neuman, 1976; Karås, 1987; Böhling et al., 1991; Lappalainen et al., 1996). Because of similar environmental dependency, synchrony in year class fluctuations of perch and pikeperch has been reported (Lappalainen et al., 1996). These species also compete for resources (e.g. Schulze et al., 2006) and reciprocally prey on each other (e.g. Lehtonen et al., 1996). Agonistic relationships between these two percids have been observed in catch-per-unit-of-effort data from many Finnish lakes, with Lake Oulujärvi being one of the best documented cases (Vainikka et al., 2017).

In general, perch fry are vulnerable to numerous predators including cannibalistic conspecifics, especially at high densities of age-0 perch (Buijse \& van Densen, 1992). Perch face particularly high predation risk during the short dispersal period following hatching when they move first to the pelagic and thereafter back to the littoral habitats (Urho, 1996). During this period, pikeperch is a significant predator for small perch (Lehtonen et al., 1996; Keskinen \& Marjomäki, 2004). Studies on the ecologically similar North American species pair suggest that walleye (Sander vitreus) reduce recruitment of yellow perch (Perca flavescens) (Hartman \& Margraf, 1993; Zhang et al., 2017a). Resource competition with pikeperch and other fish can affect adult and juvenile perch diets with significant ecological consequences. Perch normally undergo several ontogenetic niche shifts such that the main diet items shift from zooplankton to macroinvertebrates and finally to fish (Hjelm et al., 2000). Piscivorous perch have demonstrated diet alterations following a pikeperch introduction by preying more upon smaller conspecifics and macroinvertebrates (Schulze et al., 2006). On the other hand, abundant roach (Rutilus rutilus) populations have been reported to accelerate the shift of pelagic juvenile perch to the use of macroinvertebrates through competition for zooplankton (Persson \& Greenberg, 1990). In general, perch balances the trade-off between predation risk and prey availability by active habitat choices (Eklöv, 1997).

Knowledge of the stock-recruitment $(S-R)$ relationship of fish populations is essential for quantitative population modelling and effective fisheries management. Among percids, $S-R$ functions have been published for both yellow perch (e.g. Zhang et al., 2017a, b) and perch (Paxton et al., 2004). The simplest possible linear $S-R$ function includes only recruitment $(R)$ to a particular age and the spawning stock biomass $(S)$. However, adding variables and non-linearity describing key relevant ecological and environmental factors may improve the explanatory power of $S$ $R$ models. For example, incorporating the predation effects of walleye improved a $S-R$ model of yellow perch (Zhang et al., 2017a), while including Northern pike (Esox lucius) as predator, by contrast, did not improve the perch recruitment model fit (Paxton et al., 2004). Water warming rate in summer, wind speed (Zhang et al., 2017a) and infectious diseases are among factors that could affect recruitment success (Paxton et al., 2004). It is widely acknowledged that fisheries management should transform from traditional single-species approaches to ecosystem-based management, with a holistic view of aquatic ecosystem functioning (Pikitch et al., 2004). Quantitative analysis of the interactions between multiple species and environmental factors within an ecosystem is thus highly important in order to proceed in ecosystembased management (Pikitch et al., 2004).

In this study, our aim was to construct a $S-R$ model for perch in the Archipelago Sea, southwestern Baltic Sea coast of Finland, by including the potentially important ecological variables in addition to perch spawning stock size in the model. To identify potential compensation or overcompensation in the $S-R$ relationship, we fitted ecologically amended versions of the three most commonly used stock-recruitment model types (Beverton-Holt, Ricker and Saila-Lorda; 
Needle, 2001) and compared model performance. The dependence of relative year class strength of perch on summer temperatures in the boreal zone is well known (Neuman, 1976; Böhling et al., 1991; Lappalainen et al., 1996) and should be included in $S-R$ models to inform fisheries management under the current climate change regime. The potential negative effect of pikeperch on perch has been recognized in several studies in lakes (Lehtonen et al., 1996; Keskinen \& Marjomäki, 2004; Vainikka et al., 2017). While several other factors such as eutrophication (Olin et al., 2002), abundance of cyprinids (Persson \& Greenberg, 1990) and predation by other natural piscivores may also affect perch, comprehensive annual data on these factors were lacking. Moreover, as both cyprinids and pikeperch are favoured by eutrophication and warm water temperatures, a strong positive correlation between these factors is expected. Stock assessment of perch (this study) and pikeperch (Heikinheimo et al., 2014 and recent updates) in the Archipelago Sea enabled the quantification of perch spawning stock biomass and recruitment, and pikeperch population size to be used as raw data for this study.

\section{Materials and methods}

\section{Study area}

The Archipelago Sea is a low-salinity area of the Baltic Sea off the southwestern coast of Finland. It is important for commercial and recreational fisheries of both perch and pikeperch. Surface salinity varies from 4 to $8 \%$, increasing from the inner archipelago to the outer sea (Bonsdorff et al., 1997). The Archipelago Sea contains thousands of islands and has a complex topography (Bonsdorff et al., 1997), with average water depth of $23 \mathrm{~m}$ and maximum depth $>100 \mathrm{~m}$. Effects of eutrophication in the Archipelago Sea include decreased transparency, increased amounts of oxygen-consuming drifting algal mats, changes in zoobenthos and fish communities (Bonsdorff et al., 1997), and oxygen deficiency in the profundal zone (Virtasalo et al., 2005). The data used in this study cover the ICES statistical rectangles $49 \mathrm{H} 1,49 \mathrm{H} 2$ and 50H1 (Fig. 1).
Commercial and recreational fishery and perch catches

Total commercial perch catch data $(\mathrm{kg})$ used for the assessment of the perch stock were derived from commercial catch statistics from 1980 to 2014 [Official Fisheries Statistics, Natural Resources Institute Finland (Luke)], based on obligatory monthly reporting by coastal commercial fishers. The fishers report their catches, including all species, and fishing effort by gear type. The commercial perch catch is mainly captured with gillnets and trap nets. Recreational catch data originated from questionnaire surveys conducted every 2 years (Official Fisheries Statistics, Luke; Leinonen et al., 1998; Toivonen et al., 2002; Seppänen et al., 2011). The survey is based on stratified sampling of 7500 random people living in throughout Finland. To complement the responses, a sample of nonresponsive people are interviewed by telephone (https://stat.luke.fi/en/tilasto/4476/kuvaus/4989). For the stock assessment of perch, recreational catches in the years between surveys were estimated based on the relationship between commercial and recreational perch catches in the survey years. Similar interpolation was applied to the year 2010 because of the differing sampling scheme in the survey (P. Moilanen, Luke, pers. comm.; Heikinheimo et al., 2014).

Samples from commercial perch catches

Individual data were collected by the Finnish Game and Fisheries Research Institute (currently Luke) during the years $1980-2014$ by annual random sampling of commercial gillnet and trap net catches of perch in all quarters of the year (Fig. 2). The number of age-determined individuals ranged from 200 to 889 annually in 1980-1997 and from 618 to 2800 in 1998-2014, in the latter period as part of the EU Data Collection Framework. The total length and weight of the fish were measured, sex and maturity stage were determined, and one of the operculum bones was dissected for age determination. The ages were determined from the operculum bones using a binocular microscope.

Stock assessment

For the stock assessment, the age structure of perch in the annual total catches was estimated for each gear 


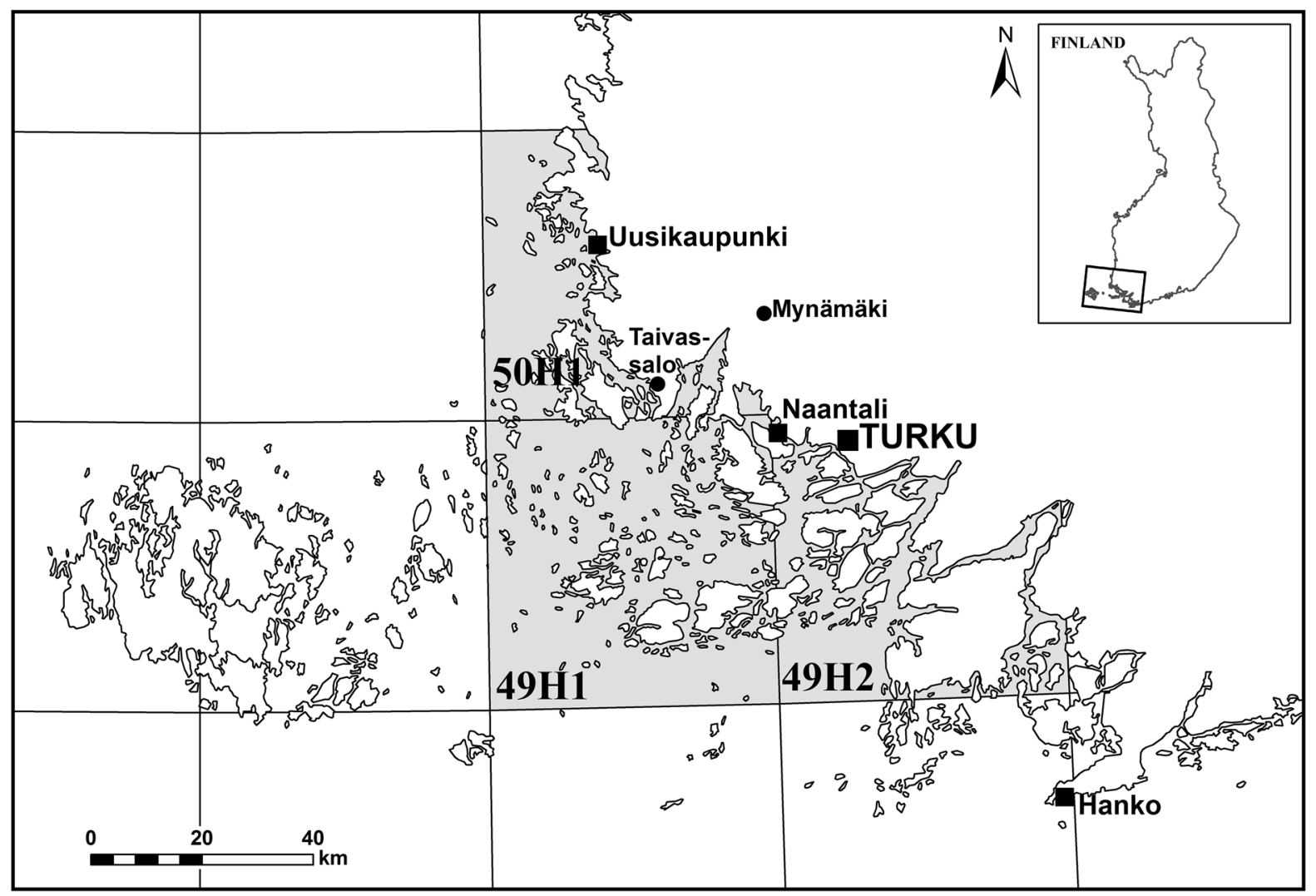

Fig. 1 Study area in the Archipelago Sea region of the Baltic, off the southwestern coast of Finland (ICES rectangles 49H1, 49H2, 50H1). Figure 1 is printed by the permission of Elsevier, modified from the Heikinheimo et al., 2014

type by using the mean weights of fish and the proportions of different age groups in the annual gearspecific catch samples. As no samples were available from the recreational catches, we assumed that the age and size distributions in the recreational gillnet catches coincide with those of the commercial gillnet catches.

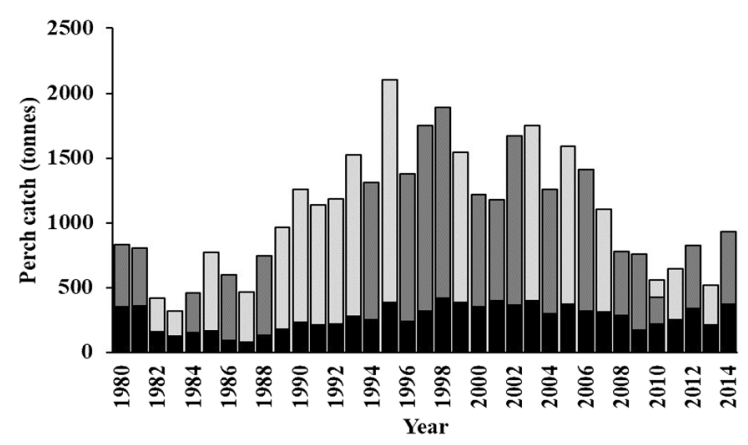

Fig. 2 Perch catches from the commercial (black) and recreational fisheries (recreational catch $=$ grey, recreational catch estimated $=$ light grey) in the Archipelago Sea
This was justified because the most commonly used mesh sizes are similar in both fisheries. As no samples were available from the recreational rod catches, we assumed a similar age structure as in the commercial trap net catches, because both gear types are generally less size-selective than gillnets (Kuparinen et al., 2009). The numbers of fish by age group in the catches of different gear types were summed up for each year to produce the age structure of perch in the total annual catches.

Stock size by age group in numbers was estimated using Pope's cohort analysis that approximates true virtual population analysis VPA (Hilborn \& Walters, 1992; see Heikinheimo et al., 2014). This method back-calculates the age-specific fishing mortalities and population size in the past years based on the annual age structure of the catch. Spawning stock biomass $(S)$ was calculated in tonnes, including perch at ages 5-14, by multiplying the numbers with annual age-specific mean weights in the commercial gillnet 
catch samples. For the years 1980-1997, gillnet samples were missing, and the age structure of trap net samples was used instead, with age-specific mean weights in the gillnet catches in 1998-2009. The number of 3-year-old individuals in each year class was used as an index of recruitment 3 years earlier, as this is the youngest age group that regularly occurs in the fisheries catches.

To estimate the initial terminal fishing mortality for the VPA, annual instantaneous total mortality $(Z)$ was calculated from the average age composition in the trap net catches in different decades using the catch curve method (Hilborn \& Walters, 1992). The total mortality in completely recruited age groups (recruitment to the fishery at ages 6-7) varied from 0.5 to 0.8 and was slightly higher for females than males (Heikinheimo \& Lehtonen, 2016). Fishing mortality $(F)$ was estimated by subtracting natural mortality $(M)$ from the total mortality. $M$ was assumed to be 0.2 at ages 3-7 and 0.1 at ages $\geq 8$ and constant over time. These values are rough estimates and $M$ is most probably not constant in the reality, but the assessed stock sizes and year class strengths are relative values. Potential variation in $M$ can be assumed to cause more unexplained variation in the results.

\section{Pikeperch population size}

The population size of the pikeperch by age group was estimated with VPA (Pope's cohort analysis) as described in Heikinheimo et al. (2014). As the calculation in the cohort analysis proceeds from the observed numbers of individuals in the fisheries catches backwards in time, the number of individuals in young age groups is greatly affected by the values of natural mortality, which are highly uncertain (Heikinheimo et al., 2016). Here, the natural mortality values from Heikinheimo et al. (2014) were used, and the age groups $\geq 1$ were included in the population size. The sensitivity of the results to the assumed $M$ of pikeperch was examined by repeating the VPA with different values of natural mortality (Heikinheimo et al., 2016) and using the population sizes derived from these trials in $S-R$ analyses (See Supplementary material for details). In general, larger $M$ values produced larger stock size estimates for young age groups and vice versa.
Water temperature data

Measurements of water temperatures were available for the period 1997-2008, from $1 \mathrm{~m}$ depth in Ruissalo, Turku, Finland (coordinates: latitude 60.43, longitude 22.10, EUREF FIN, corresponds to WGS84, Finnish Meteorological Institute). For the earlier years (19801996), the water temperatures were modelled based on daily air temperature data from Turku Airport (coordinates: latitude 60.52, longitude 22.48, EUREF FIN) with four measurements recorded each day by the Finnish Meteorological Institute (Kjellman et al., 2003; Pekcan-Hekim et al., 2011; Heikinheimo et al., 2014). For the year 2009, the water temperatures were modelled similarly using air temperatures measured in Turku, Artukainen (coordinates: latitude 60.45, longitude 22,18, EUREF FIN, Finnish Meteorological Institute) because data from the airport were not available. Water temperatures were estimated for the period from first of May to 30th of September. The equation of Kjellman et al. (2001) was used for the estimation for missing daily water temperatures:

$T_{W d}=a+T_{W(d-1)}+b\left(T_{A(d-1)}-T_{W(d-1)}\right)$,

where $T_{W}$ is surface water temperature $(0-1 \mathrm{~m}), T_{A}$ is air temperature, and $d$ is day. Coefficients $a(0.1135)$ and $b(0.0821)$ were estimated using least-squares regression $\left(R^{2}=0.9\right)$. The estimated water temperatures were based on the difference between air temperature $\left(T_{A(d-1)}\right)$ and water temperature the previous day $\left(T_{W(d-1)}\right)$.

\section{Stock-recruitment analyses}

We used Ricker (Ricker, 1954), Beverton-Holt (Beverton \& Holt, 1957) and Saila-Lorda (Saila et al., 1988) types of the $S-R$ relationships amended with the effects of temperature and pikeperch stock size as environmental variables. The main difference between the model types lies in the form of densitydependent compensation, which may cause the recruitment to level out (Beverton-Holt, compensation) or decrease (Ricker and Saila-Lorda, overcompensation) with high spawning stock biomass. The Saila-Lorda model includes an additional possibility of depensatory mechanism at low stock levels, when $\gamma$-parameter is $>1$ (Iles, 1994). Spawning stock biomass $(S)$ was estimated assuming a constant 
Table 1 Model types and equations

\begin{tabular}{ll}
\hline Model Equation &
\end{tabular}

Density-independent stock-recruitment model

Ricker stock-recruitment model (Ricker, 1954)

Ricker stock-recruitment model with one environmental variable (pikeperch)

Ricker stock-recruitment model with one environmental variable (temperature)

Ricker stock-recruitment model with two environmental variables (pikeperch and temperature)

Beverton-Holt stock-recruitment model (Beverton \& Holt, 1957)

Beverton-Holt stock-recruitment model with one environmental variable (pikeperch)

Beverton-Holt stock-recruitment model with one environmental variable (temperature)

Beverton-Holt stock-recruitment model with two environmental variables (pikeperch and temperature)

Saila-Lorda stock-recruitment model (Saila et al., 1988)

Saila-Lorda stock-recruitment model with one environmental variable (pikeperch)

Saila-Lorda stock-recruitment model with one environmental variable (temperature)

Saila-Lorda stock-recruitment model with two environmental variables (pikeperch and temperature)

Ricker stock-recruitment model in logarithmic form

Ricker stock-recruitment model with one environmental variable (pikeperch) in logarithmic form)

Ricker stock-recruitment model with one environmental variable (temperature) in logarithmic form

Ricker stock-recruitment model with two environmental variables (pikeperch and temperature) in logarithmic form

$$
\begin{aligned}
& R=a S \\
& R=S \times e^{(a-b S)} \\
& R=S \times e^{(a-b S+c(E 1-\bar{E} 1))} \\
& R=S \times e^{(a-b S+d(E 1-\bar{E} 1))} \\
& R=S \times e^{(a-b S+c(E 1-\bar{E} 1)+d(E 2-\bar{E} 2))} \\
& R=(S \times a)(b+S)^{-1} \\
& R=(S \times a)(b+S)^{-1} \times e^{(c(E 1-\bar{E} 1))} \\
& R=(S \times a)(b+S)^{-1} \times e^{(d(E 1-\bar{E} 1))} \\
& R=(S \times a)(b+S)^{-1} \times e^{(c(E 1-\bar{E} 1)+d(E 2-\bar{E} 2))} \\
& R=a \times\left(S^{\gamma}\right) \times e^{(-b S)} \\
& R=a \times\left(S^{\gamma}\right) \times e^{(-b S+c(E 1-\bar{E} 1))} \\
& R=a \times\left(S^{\gamma}\right) \times e^{(-b S+d(E 1-\bar{E} 1))} \\
& R=a \times\left(S^{\gamma}\right) \times e^{(-b S+c(E 1-\bar{E} 1)+d(E 2-\bar{E} 2))} \\
& \ln R S^{-1}=a-b S \\
& \ln R S^{-1}=a-b S+c(E 1-\bar{E} 1) \\
& \ln R S^{-1}=a-b S+d(E 2-\bar{E} 2) \\
& \ln R S^{-1}=a-b S+c(E 1-\bar{E} 1)+d(E 2-\bar{E} 2)
\end{aligned}
$$

$R=$ recruitment, $S=$ spawning stock biomass, $a, b$, and $\gamma$ are parameters of the stock-recruitment models, $c=$ coefficient for pikeperch population size, $E 1=$ pikeperch population size, $\bar{E} 1=$ average pikeperch population size during the study period, $d=$ coefficient for temperature, $E 2=$ temperature, $\bar{E} 2=$ average temperature during the study period

maturation age of five as there were only very few mature individuals at age 4 in the catch samples. Recruitment ( $R$, to age three) was predicted with a density-independent $S-R$ model in addition to the three $S-R$ models listed above and their extended versions incorporating the effect of pikeperch population size $\left(P_{t}\right)$ and temperature $\left(T_{t}\right)$ as environmental variables in the summer spawning occurred (i.e. the year class was born $(t)$, and $t+3=$ the year of recruitment at age three) (Table 1). $\mathrm{R}$ version 3.3.2 (R Core Team) was used to fit the $S-R$ models.

The effects of potentially important environmental variables (temperature in different months and different age groups included in the pikeperch population size with optional values of natural mortality) were tested using the Ricker equation in logarithmic form (using multiplicative error structure) (Table S2). In these explorations, linear models with ordinary leastsquares regression were used. $T$ and $P$ (updated from Heikinheimo et al., 2014) were included in the $S$ $R$ functions as anomalies (absolute deviations from the mean during 1981-2009). Several temperature periods were tested to determine the most influential period: June-September, June-August, June-July, July, and June. We also studied the influence of different pikeperch age groups included in $P$ to find the most influential age and size groups of pikeperch (age of pikeperch in the hatching year of the perch year class): age 1 , ages $1-2$, ages $\geq 1$, ages $\geq 2$, and ages $\geq 3$. The effect of higher natural mortality of young 
pikeperch was also explored (Supplementary material).

In the final analyses with all model types, we used mean water temperature in June-July and $P$ including ages $\geq 1$. Non-linear regression with Gauss-Newton algorithm was used to fit the non-linear model versions with additive error structure and 95\% confidence intervals for the parameters were estimated with "NLS-tools" package using bootstrapping with 999 iterations. Three-dimensional figures to predict $R$ with the best $S-R$ models with changing values of $S$ and $P$ (with $T$ kept constant at anomaly $=0$ ) or of $S$ and $T$ (with $P$ kept constant at anomaly $=0$ ) were drawn with Matlab R2017b.

Evaluation of the candidate stock-recruitment models

Statistical comparison of the fit of the $S-R$ equations is challenging. The Saila-Lorda model is a generalization of the Ricker model, thus making their comparison possible (as the models are nested), while the Beverton-Holt model cannot be compared to Ricker or Saila-Lorda models (models are non-nested) (Iles, 1994). $S-R$ models can be compared with densityindependent models and within the $S-R$ type in nested versions with additional variables (Ogle, 2015). For linearized models (e.g. models 14-17 in Table 1, Supplementary material, Tables S1, S3), adjusted $r^{2}$ and AIC and BIC were used for comparisons. For nonlinear models, $r^{2}$ values are not interpretable (e.g. Spiess \& Neumeyer, 2010), and quasi- $r^{2}$ values can be used instead (Ogle, 2015). Small quasi- $r^{2}$ values imply low fit of the model, while higher values are not directly comparable (Ogle, 2015). The quasi- $r^{2}$ value was calculated as the squares of Pearson's correlation coefficient between the observed and predicted $R$ (Maceina \& Pereira, 2007). To compare the linear and nonlinear models to each other, quasi- $r^{2}$ values were also calculated for the best linearized Ricker model. Quasi$r^{2}$ values were used for comparison of both nested and non-nested models.

The non-linear models with statistically comparable nested $S-R$ structures were compared based on AIC, BIC, quasi- $r^{2}$ values and extra sums-of-squares (ExtraSS) test included in the " $F S A$ " package (Ogle, 2015). The model fit was also evaluated using bootstrapped confidence intervals, as more than $1 \%$ of iterations facing convergence problems typically indicate problems in the model fit (Ogle, 2015). Sensitivity of the best models to the chosen natural mortality and included number of pikeperch ages in the calculation of pikeperch biomass were explored. To make sure that strongly deviating individual data points did not influence the results, the final models were fitted also without years 1988 and 1993 in the data.

\section{Results}

Stock assessment

Year class strengths of perch fluctuated widely especially in the 1980s and 1990s, with the peak recruitment years coinciding with warm summers (Fig. 3). However, in some years (1991 and 1996) moderately good year classes were established at low June-July temperatures (Fig. 3). There was no linear trend in the average June-July water temperature ( $\left.F_{1,27}=0.56, P=0.462\right)$ during the study period. The spawning stock biomass of perch was at highest in 1993 and 2002, while the abundance of pikeperch increased during the study period, being at the highest in the end of the 1990s and in the early 2000s (Fig. 3).

Stock-recruitment relationship and the effects of temperature and pikeperch

All $S-R$ models without environmental variables (Fig. 4) had significantly better fits than the densityindependent model (ExtraSS: Ricker $F=7.16, d f=1$, $p=0.012$, Beverton-Holt $F=8.09, d f=1, p=0.008$ and Saila-Lorda $F=3.87, d f=1, p=0.034) . S-$ $R$ models without environmental variables had very low quasi- $r^{2}$ values (0.01-0.02) (Table 2), and the Saila-Lorda model did not perform better than the Ricker model (ExtraSS: $F=0.68, d f=1, p=0.418$ ).

Adding environmental variables (June-July temperature and pikeperch stock size ages $\geq 1$ ) improved the model fits, and the best models included both variables (Table 2). The predicted recruitment of perch followed quite well the observed recruitment in all of those three best models (Ricker, BevertonHolt and Saila-Lorda with pikeperch population size age $\geq 1$ anomaly and June-July temperature anomaly) (Fig. 5). The Saila-Lorda model with both environmental variables was not statistically 
(a)

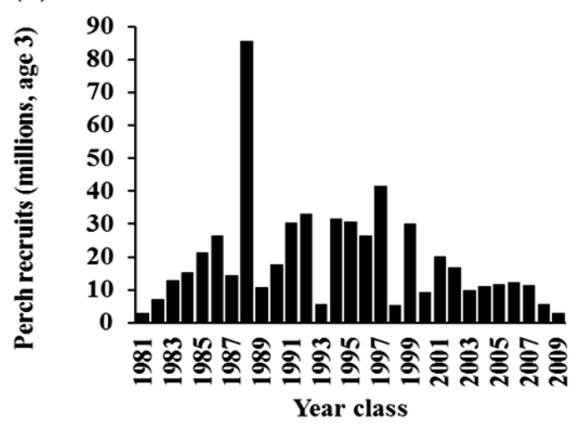

(c)

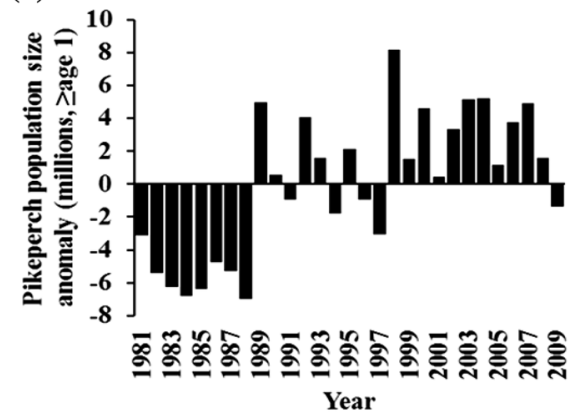

Fig. 3 a Number of perch recruits (age 3, in millions), b perch spawning stock biomass (ages 5-14 in tonnes), c pikeperch population size (ages $\geq 1$, anomaly from the average

significantly better than the Ricker model with both environmental variables (ExtraSS: $F=0.221, d f=1$, $p=0.643)$, although the quasi- $r^{2}$ value was greatest in the Saila-Lorda model (Table 2). The best Ricker and Beverton-Holt models had quasi- $r^{2}$ values close to each other (Table 2). In these models, all parameters

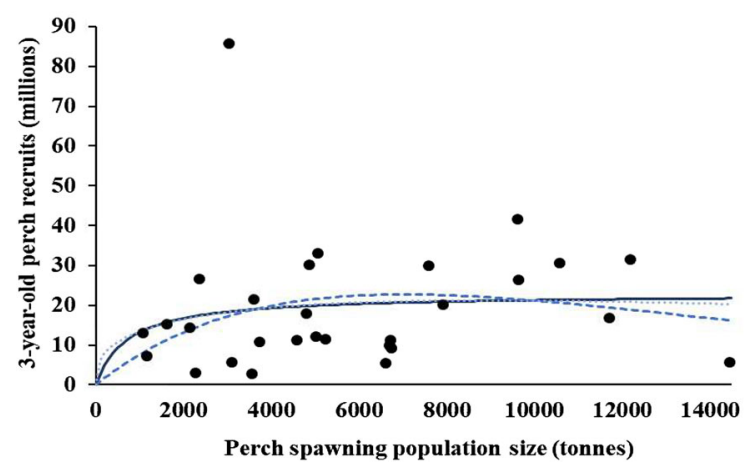

Fig. 4 Basic stock-recruitment models: Beverton-Holt (continuous line), Ricker (broken line) and Saila-Lorda (dotted line) fitted to the estimated number of perch recruits (age 3 in millions) from the VPA (black points), plotted against perch spawning stock biomass ( $S$ in tonnes, age 5-14) (b)

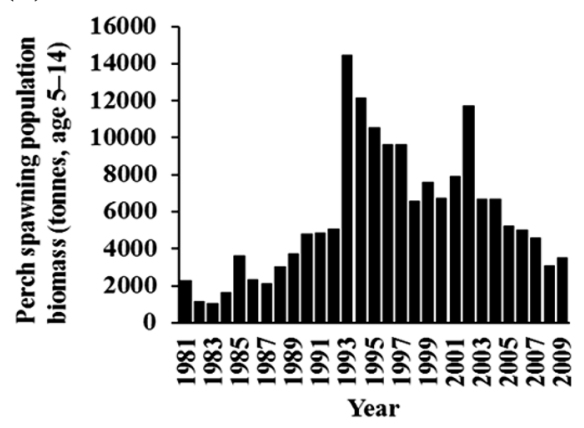

(d)

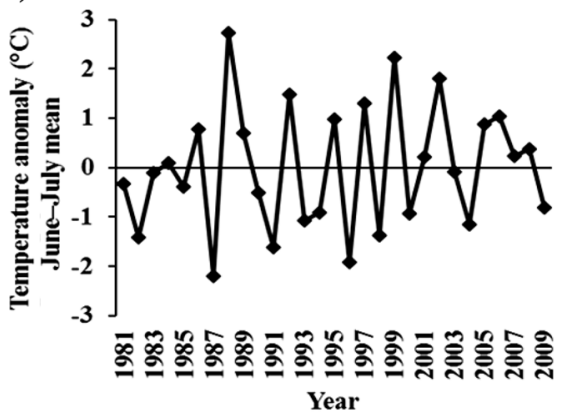

1981-2009), and d annual average temperature in June-July (anomaly from the average 1981-2009)

were statistically significant except for the $b$ in the Beverton-Holt and both $a$ and $b$ in the Saila-Lorda model (Table 3 ). There were no clear trends in the residuals of the best $S-R$ models (in Fig. 5 BevertonHolt model residuals as an example). Based on the quasi- $r^{2}$ values, the models fitted better with the additive error structure used in non-linear models than with the multiplicative error structure used in the fitting of the linearized versions (Table 2).

In the predictions based on the best models, perch recruitment increased when water temperature increased (Fig. 6) and decreased when pikeperch stock sizes increased (Fig. 7). When examining the sensitivity of the results to the natural mortality assumption and number of pikeperch ages included in the population size calculations, the goodness of fits remained at original level and the model predictions were impacted quite minimally (Supplementary material). Years 1988 and 1993 were influential on the good fit of the best models, because without these years quasi- $r^{2}$ values decreased to $0.594-0.598$. 
Table 2 Comparison of models ordered based on quasi- $r^{2}$ values

\begin{tabular}{|c|c|c|c|c|c|}
\hline Model & $\begin{array}{l}\text { Conditions of } \\
\text { admissibility }\end{array}$ & $\begin{array}{l}\text { Problems in CI } \\
\text { bootstrap convergence }\end{array}$ & $\begin{array}{l}\text { Quasi- } \\
r^{2}\end{array}$ & $\mathrm{AIC}$ & $\mathrm{BIC}$ \\
\hline $\begin{array}{l}\text { 13. Saila-Lorda with pikeperch and temperature as } \\
\text { environmental variables }\end{array}$ & Met & & 0.774 & 1014 & 1022 \\
\hline $\begin{array}{l}\text { 5. Ricker with pikeperch and temperature as environmental } \\
\text { variables }\end{array}$ & Met & & 0.771 & 1012 & 1019 \\
\hline $\begin{array}{l}\text { 9. Beverton-Holt with pikeperch and temperature as } \\
\text { environmental variables }\end{array}$ & Met & & 0.765 & 1013 & 1020 \\
\hline $\begin{array}{l}\text { 17. Ricker with pikeperch and temperature as environmental } \\
\text { variables (multiplicative error structure) }\end{array}$ & & & 0.728 & 58 & 65 \\
\hline 4. Ricker with temperature as environmental variable & Met & & 0.488 & 1037 & 1042 \\
\hline 11. Saila-Lorda with pikeperch as environmental variable & Met & $1 / 999$ & 0.469 & 1037 & 1043 \\
\hline 3. Ricker with pikeperch as environmental variable & Met & & 0.430 & 1037 & 1042 \\
\hline 7. Beverton-Holt with pikeperch as environmental variable & Met & $38 / 999$ & 0.407 & 1038 & 1043 \\
\hline $\begin{array}{l}\text { 15. Ricker with pikeperch as environmental variable } \\
\text { (multiplicative error structure) }\end{array}$ & & & 0.398 & 64 & 69 \\
\hline $\begin{array}{l}\text { 16. Ricker with temperature as environmental variable } \\
\text { (multiplicative error structure) }\end{array}$ & & & 0.251 & 70 & 76 \\
\hline 6. Beverton-Holt & Met & $16 / 999$ & 0.020 & 1050 & 1054 \\
\hline 10. Saila-Lorda & Met & $312 / 999$ & 0.019 & 1052 & 1058 \\
\hline 14. Ricker (multiplicative error structure) & & & 0.014 & 73 & 77 \\
\hline 2. Ricker & Met & & 0.013 & 1051 & 1055 \\
\hline 1. Density-independent model & Met & & 0.009 & 1056 & 1059 \\
\hline 8. Beverton-Holt with temperature as environmental variable & $b<0$ & & & 1034 & 1040 \\
\hline 12. Saila-Lorda with temperature as environmental variable & $\gamma<0$ & & & 1035 & 1042 \\
\hline
\end{tabular}

Non-linear models have additive error structure, linear models multiplicative error structure. Conditions of admissibility (Iles, 1994) and problems in $95 \%$ CI bootstrap convergence occurred in the non-linear models

\section{Discussion}

We found that perch recruitment was affected not only by perch spawning stock biomass but by water temperature and pikeperch stock size in the Archipelago Sea region of the Baltic Sea. Thus, the fitted stock-recruitment functions can be efficiently used to further model the responses of perch stock to varying ecological and environmental conditions (c.f. Szuwalski et al., 2015). However, the performance of different types of best $S-R$ models (Ricker, Beverton-Holt and Saila-Lorda with pikeperch population size age $\geq 1$ anomaly and June-July temperature anomaly) was very similar suggesting that within the observed stock range, both depensatory and overcompensatory mechanisms are unlikely but may occur at more extreme stock biomasses. Despite our inability to make a distinction between the model types, density- dependent models fitted better than density-independent models demonstrating that perch recruitment per unit of spawning stock biomass is reduced at high stock sizes. The models also suggest that the environment sets an upper limit for the recruitment. The decline in perch abundance in the outer archipelago (Ljunggren et al., 2010) may suggest that perch reproduction is currently limited to restrained areas close to the coast.

When perch spawning stock biomass is very large, recruitment could be reduced through cannibalism or intraspecific scramble competition leading to starvation of most of the offspring (Brännström \& Sumpter, 2005). Cannibalism is common in perch (Buijse \& van Densen, 1992) and can partly explain recruitment variation (Persson et al., 2000). However, competitive interactions among different-sized perch can affect recruitment to older ages, e.g. young-of-the-year perch 
Fig. 5 a 3-year-old perch recruits in millions ( $y$-axis) and year class ( $x$-axis), data points (black points) and the predicted recruitment of the $S-R$ models: Beverton-Holt (continuous line), Ricker (broken line) and SailaLorda (dotted line), with pikeperch population size (ages $\geq 1$ ) and average June-July temperature as environmental variables. b Residuals of the Beverton-Holt model with pikeperch population size (ages $\geq 1$ ) and average June-July temperature as environmental variables. Note that in the cohort analysis the strengths of the most recent year classes (2007-2009) are uncertain and affected by the estimate of fishing mortality in the terminal year
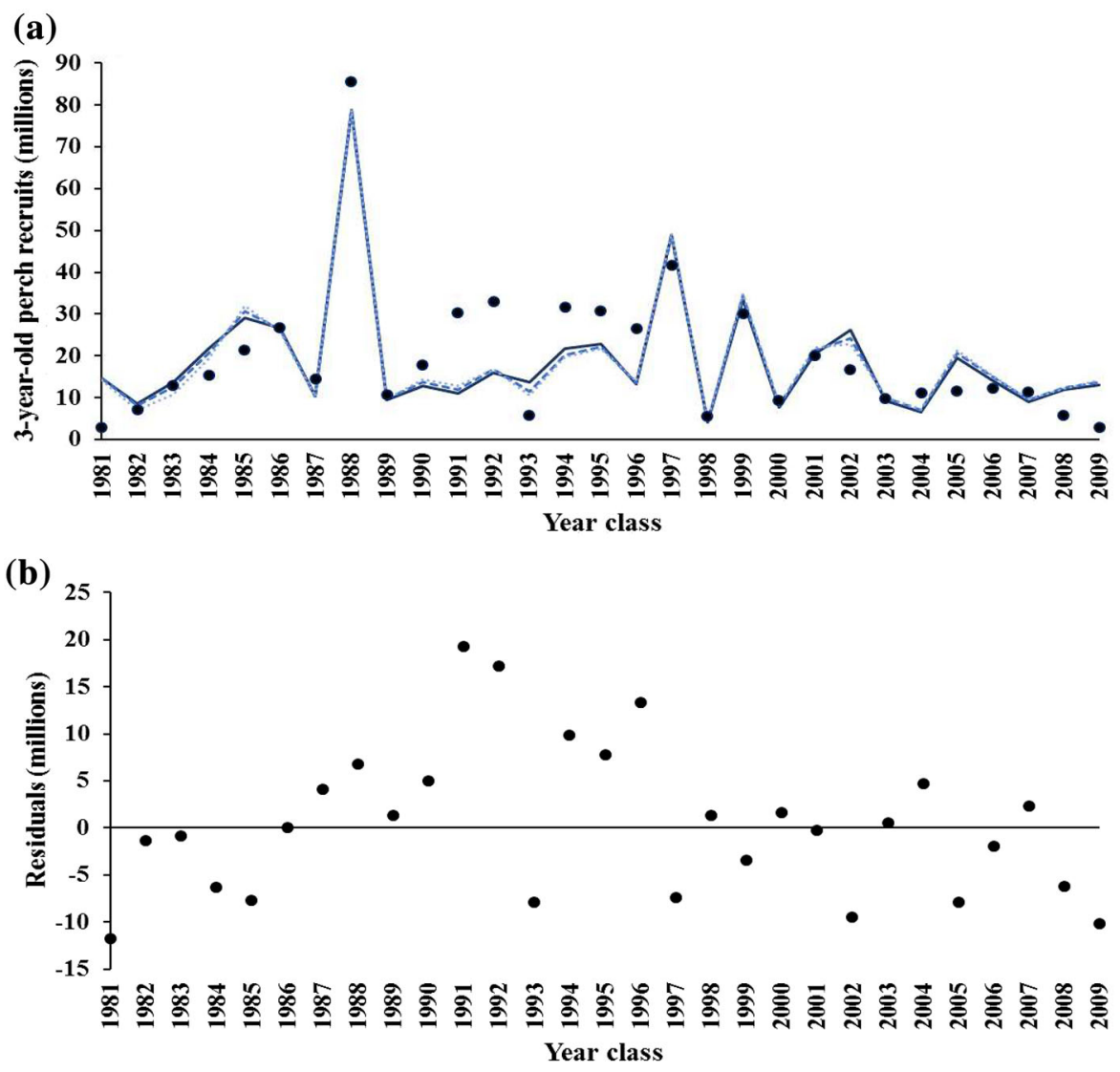

may have an advantage over age one perch in competition because of their relatively higher efficiency in the utilization of zooplankton (Persson et al., 1998, 2000). In Perciformes, both overcompensatory and nearly density-independent $S-R$ relationships have been observed (Szuwalski et al., 2015). In intensively harvested stocks such as Archipelago Sea perch, spawning stock biomass may not reach levels above which overcompensation can occur (Hilborn \& Walters, 1992).

Saila-Lorda models incorporate depensation at low levels of spawning stock biomass. Depensation means that low stock levels reduce the recruitment per spawning stock biomass and therefore low stock levels should be avoided in order to minimize the risk of the stock collapse. The $\gamma$-parameter in the SailaLorda model was statistically significant and $>1$, indicating a risk for depensatory Allee effects at low stock abundances (Iles, 1994; Perälä \& Kuparinen, 2017). Our study shows that depensation could occur despite the production of up to 6000 eggs by one female perch, suggesting a threshold number of reproductive pairs and good spatial coverage of spawning are needed to ensure successful recruitment in a spatially and temporally varying environment (Neuman et al., 1996, Persson et al., 2000).

This study confirmed that temperature positively affects perch recruitment in the Baltic Sea (Neuman, 1976; Böhling et al., 1991; Lappalainen et al., 1996) which is likely mediated by growth during first warm summer resulting in lower size-dependent mortality during the first winter (Karås, 1987). At the level of June-July temperatures observed in the study period $\left(14.0-18.9^{\circ} \mathrm{C}\right.$, average $\left.16.2^{\circ} \mathrm{C}\right)$ and with average pikeperch population size, predicted perch recruitment was highest at the highest temperatures (Fig. 6). Although there was no linear temporal trend in the June-July temperatures in this study, average temperatures during the whole growing season have increased by $0.9^{\circ} \mathrm{C}$ from 1980 to 2008 (Pekcan-Hekim 
Table 3 Estimated parameters (P) of the best models (17 = Ricker with pikeperch and temperature as environmental variables, $9=$ Beverton-Holt with pikeperch and temperature as environmental variables, $13=$ Saila-Lorda with pikeperch and temperature as environmental variables) with standard errors (SE), $t$ value, significance ( $p$ value), residual standard error (Residual SE), degrees of freedom (df), lower confidence limit (95\% LCL) and upper confidence limit (95\% UCL)

\begin{tabular}{|c|c|c|c|c|c|c|c|c|c|}
\hline Model & $\mathrm{P}$ & Mean & $\mathrm{SE}$ & $t$ value & $p$ value & $\begin{array}{l}\text { Residual } \\
\text { SE }\end{array}$ & $\mathrm{df}$ & $95 \% \mathrm{LCL}$ & $95 \% \mathrm{UCL}$ \\
\hline \multirow[t]{4}{*}{17.} & $a$ & 8.68 & 0.21 & 40.57 & $<2 \times 10^{-16}$ & $8.34 \times 10^{6}$ & 25 & 8.27 & 9.06 \\
\hline & $b$ & $1.00 \times 10^{-4}$ & $2.56 \times 10^{-5}$ & 3.92 & $6.11 \times 10^{-4}$ & & & $5.21 \times 10^{-5}$ & $1.48 \times 10^{-4}$ \\
\hline & $c$ & $-1.33 \times 10^{-7}$ & $2.25 \times 10^{-8}$ & -5.92 & $3.57 \times 10^{-6}$ & & & $-1.75 \times 10^{-7}$ & $-9.61 \times 10^{-8}$ \\
\hline & $d$ & 0.31 & 0.05 & 5.92 & $3.50 \times 10^{-6}$ & & & 0.22 & 0.41 \\
\hline \multirow[t]{4}{*}{9.} & $a$ & $3.11 \times 10^{7}$ & $8.54 \times 10^{6}$ & 3.64 & $1.25 \times 10^{-3}$ & $8.47 \times 10^{6}$ & 25 & $1.98 \times 10^{7}$ & $6.35 \times 10^{7}$ \\
\hline & $b$ & 4296 & 2738 & 1.57 & 0.13 & & & 1061 & $1.52 \times 10^{4}$ \\
\hline & $c$ & $-1.33 \times 10^{-7}$ & $2.49 \times 10^{-8}$ & -5.34 & $1.57 \times 10^{-5}$ & & & $-1.80 \times 10^{-7}$ & $-8.86 \times 10^{-8}$ \\
\hline & $d$ & 0.33 & 0.05 & 6.00 & $2.87 \times 10^{-6}$ & & & 0.23 & 0.43 \\
\hline \multirow[t]{5}{*}{13.} & $a$ & 878 & 3769 & 0.23 & 0.82 & $8.47 \times 10^{6}$ & 24 & 0.08 & $7.49 \times 10^{5}$ \\
\hline & $\gamma$ & 1.25 & 0.57 & 2.21 & 0.04 & & & 0.35 & 2.47 \\
\hline & $b$ & $1.42 \times 10^{-4}$ & $9.70 \times 10^{-5}$ & 1.47 & 0.16 & & & $-1.84 \times 10^{-5}$ & $3.37 \times 10^{-4}$ \\
\hline & $c$ & $-1.37 \times 10^{-7}$ & $2.48 \times 10^{-8}$ & -5.54 & $1.07 \times 10^{-5}$ & & & $-1.84 \times 10^{-7}$ & $-9.66 \times 10^{-8}$ \\
\hline & $d$ & 0.31 & 0.06 & 5.39 & $1.55 \times 10^{-5}$ & & & 0.21 & 0.41 \\
\hline
\end{tabular}

et al., 2011). Spring temperatures might also negatively affect the survival of both perch and yellow perch larvae, as early warming in spring has been shown to be disadvantageous possibly due to early hatching of larvae and increased risk of cold weather and starvation during subsequent development (Kjellman et al., 2003; Zhang et al., 2017a).

The negative effect of pikeperch on perch recruitment was most likely caused by predation although this was not confirmed with the catch data in this study. Pikeperch predation on small perch is a wellknown phenomenon in lakes (Vehanen et al., 1998; Keskinen \& Marjomäki, 2004; Keskinen, 2008) with similar dynamics as in yellow perch predation by walleye (e.g. Hartman \& Margraf, 1993; Zhang et al., 2017a). In Lake Oulujärvi, the recovering pikeperch stock consumed mostly smelt (Osmerus eperlanus) and vendace (Coregonus albula), whereas other percids were the third most utilized diet component (Vehanen et al., 1998). Vainikka et al. (2017) detected a negative relationship between pikeperch and perch gillnet catches per unit of effort (CPUE) in Lake Oulujärvi, potentially indicating high predation of pikeperch on perch. Further, perch was the second most important prey in the pikeperch diet after smelt in lake data from Central Finland (Keskinen \&
Marjomäki, 2004). According to the model estimation by Keskinen (2008), the pikeperch stock in Lake Jyväsjärvi consumed $8-59 \%$ of the perch population annually. The age of the consumed perch depended on the population structure, but predation affected mostly age $0+$ and $1+$ perch (Keskinen, 2008). In North America, walleye predation is most prevalent on young-of-the-year yellow perch (Rudstam et al., 1996).

In this study, pikeperch and temperature are found to be important ecological drivers of perch recruitment in the Archipelago Sea, but there are also other potentially important ecological factors. Potential effect of the population recovery of the great cormorant (Phalacrocorax carbo sinensis) on fish stocks has been debated intensively (Salmi et al., 2015; Heikinheimo \& Lehtonen, 2016; Heikinheimo et al. 2016). Perch is one of the most common species in the cormorant diet, with cormorants preferentially consuming smaller fish than size classes taken by fisheries (Lehikoinen et al., 2011; Salmi et al., 2015). The cormorant population in the Archipelago Sea demonstrated growth from 2000 to 2008, after which the population growth has decelerated (Finnish Environment Institute, 2017). As the time series studied here starts in the 1980, and the $S-R$ models with 
(a)

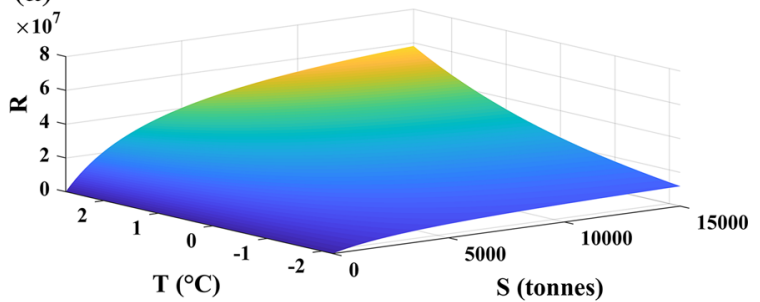

(b)

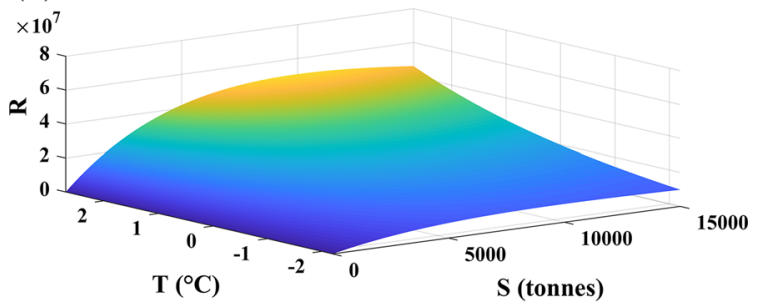

(c)

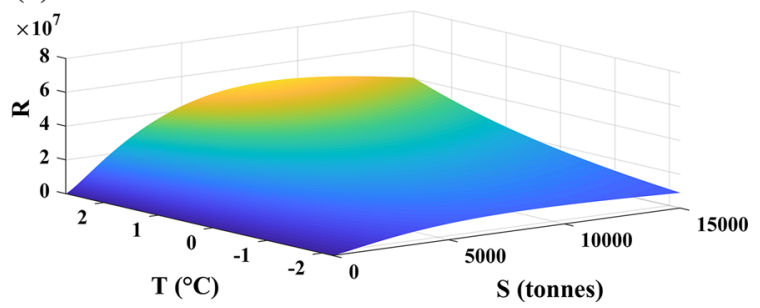

Fig. 6 Predictions for perch recruitment $(R)$ with constant pikeperch population size (anomaly $=0$ ) showing the effects of spawning stock biomass ( $S$, tonnes) and temperature $\left(T,{ }^{\circ} \mathrm{C}\right.$, anomaly). a Beverton-Holt, b Ricker and c Saila-Lorda models

temperature and pikeperch effects fit well to the observed recruitment during the whole period, any additional significant mortality sources seem not to have affected the observed recruitment trend. As the natural mortality estimates used in the stock assessment for perch were assumed constant, the cormorant effect could be seen as negative residuals during the period when the cormorants were present. Moreover, the total mortality estimated for perch showed no increase after the establishment and population growth of the cormorants (Heikinheimo \& Lehtonen, 2016) and no decreasing trends in perch CPUE in the commercial gillnet fishery were observed (Lehikoinen et al., 2017). Notably, the estimated fish consumption by predatory fish in the Archipelago Sea is considerably greater than that of cormorants (Heikinheimo et al., 2018).

Negative effects of pikeperch on perch recruitment could also arise from interspecific competition at different ages and sizes. Interspecific competition has (a)

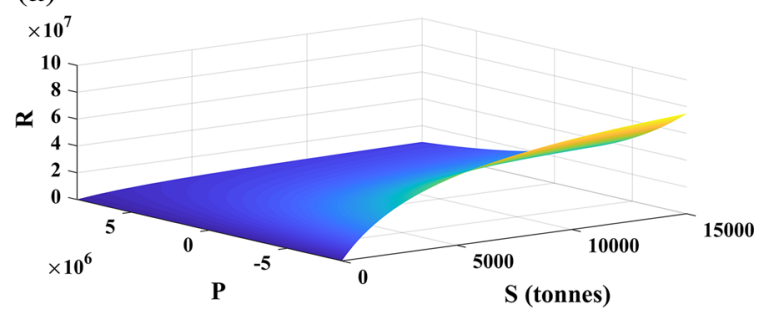

(b)

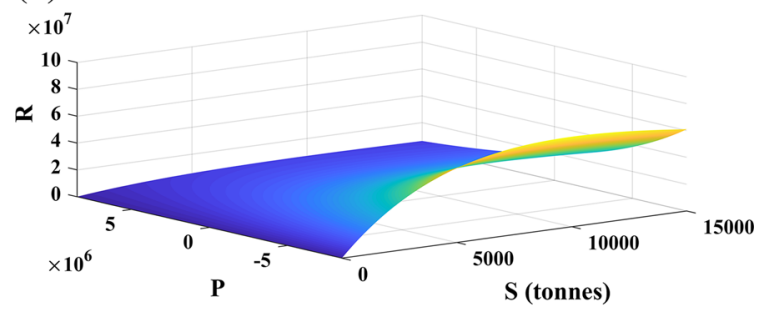

(c)

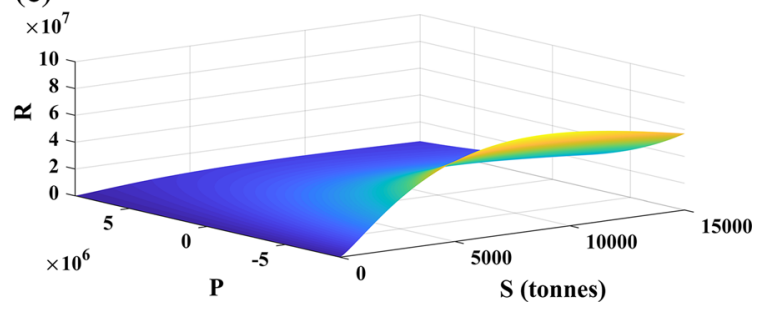

Fig. 7 Predictions for Eurasian perch recruitment $(R)$ with constant temperature (anomaly $=0$ ) showing the effects of spawning stock biomass ( $S$, tonnes) and pikeperch population size $(P$, anomaly). a Beverton-Holt, $\mathbf{b}$ Ricker and $\mathbf{c}$ Saila-Lorda models

been documented between pikeperch and large, mainly piscivorous perch (Schulze et al., 2006). As coastal Archipelago Sea bays are important reproduction areas for many species (Kallasvuo et al., 2017), interactions with species other than pikeperch might also play a role in perch recruitment. While pikeperch population sizes have grown, an increase in cyprinid abundance has been observed in the study area (Bergström et al., 2016; HELCOM, 2018). It is plausible that competition with cyprinids during juvenile stages could affect perch recruitment negatively (e.g. Persson \& Greenberg, 1990), but unfortunately there were no annual data for cyprinid abundance to be included in this study.

Years 1988 and 1993 were influential on the model fits, but their abandonment from the data would not be biologically feasible. In 1988, recruitment was exceptionally high due to the warm summer temperatures despite the low perch spawning stock biomass. In 
1993, perch spawning stock biomass was exceptionally high, but water temperatures were low and pikeperch stock was at above-average level. The largest deviations between the predicted and estimated recruitment occurred in the 1990s, which might be explained by the sources of error in the recreational fishing surveys. Methods used in the recreational fishery surveys may have resulted in underestimation of catches in the 1980s (Leinonen, 1993) and overestimation of the catches in the 1990s (Moilanen, 2001). From 1998 onwards, the survey methods were improved to compensate for non-responsiveness in the questionnaires. However, response activity has declined again in recent years (Heikinheimo et al., 2014). According to the surveys, the recreational catches have remained at low levels since the end of 2000s compared to earlier years. This may be partly due to the increased share of rod fishing, and to the fact that the catches of rod fishers coming from other parts of Finland (allowed since 1998) are registered as being caught in their main fishing area (P. Moilanen, Luke, pers. comm.), which leads to underestimation of the recreational catches in the Archipelago Sea. Compared to the commercial perch catches, the estimated recreational catches were more than fourfold in the 1990s until 1998, about threefold in the 2000s, but less than twofold in the 2010s.

The recruitment estimates for the most recent years in the cohort analysis are the most uncertain because average fishing mortality from previous years is used for the terminal year, and a potential bias affects the results a few years backwards. A recent update of the perch stock assessment, including data from the years 2015 and 2016 (Raitaniemi \& Heikinheimo, 2018), resulted in a better fit to the predicted values for perch year classes 2008 and 2009. The numbers of recruits in year classes 2008 and 2009 reached 9-10 million with constant fishing mortality or 16 million when lower terminal fishing mortality was used based on the gillnet fishing effort. The level of natural mortality in pikeperch is yet another source of uncertainty, as it affects the estimated population size of the young age groups (Heikinheimo et al., 2016). Because of the backward calculation in the cohort analysis, the population size with low natural mortality including ages $\geq 1$ can be almost equal to the population size one year later from age two upwards when higher natural mortality is assumed (see Supplementary material; Heikinheimo et al., 2016). The age at which perch are vulnerable to pikeperch predation is not known. At age 0, perch are more exposed to the predation during the pelagic dispersal phase and after the first summer (Urho, 1996). However, the potential negative effect of pikeperch predation on perch found in this study might occur at any age before recruitment at age three, and include multiple mechanisms.

Migrations can affect perch catches, since in the archipelago areas perch may sometimes move distances over ten kilometres (Böhling \& Lehtonen, 1984). However, our study area covered the most important spawning and fishing areas of both perch and pikeperch, so potential migration should have a negligible effect and manifest itself most likely as unexplained residual variation without temporal trends.

In general, stock-recruitment functions are key components in the fish population models, used to derive management reference points and future projections for the stock development (Needle, 2001). Considering the spawning stock biomass, the key management objective should be to avoid entering a depensatory zone that would turn detrimental for the fishery. The objective to avoid depensation in the population by allowing the stock to recover is better reached by using an empirical stock-recruitment function than by assuming constant recruitment (Punt, 1997). For the ecosystem-based management and adaptation regimes to the global climate change, development of stock-recruitment models that incorporate environmental effects is greatly needed. In this study, we were able to link perch spawning stock to both depensation risk and compensation while predicting recruitment variation based on water temperature and pikeperch population size. While the "black box" obscuring perch demographics prior to fisheries recruitment starting at the age of 3 years would be optimally mechanistically understood in any population modelling attempt, the stock-recruitment functions we generated provide tools to predict the future perch catches when spawning conditions are known.

Summer temperatures can be useful in predicting year class strengths and future catches for both perch and pikeperch (Pekcan-Hekim et al., 2011; Heikinheimo et al., 2014). Fisheries managers should also consider the interaction between perch and pikeperch: Pikeperch fishing is predicted to benefit perch recruitment, but perch fishing may lead to by-catch of juvenile pikeperch under the minimum legal landing 
size. Temperature-driven synchrony in the abundance of both species calls for species-specific fishing methods, while competitive interactions might call for periodically updated management targets.

Acknowledgements Open access funding provided by University of Eastern Finland (UEF) including Kuopio University Hospital. We thank all the field and laboratory workers for data collection and analysis. We thank Tommi Perälä for useful discussions about stock-recruitment analyses. The data used in this study were received from the Natural Resources Institute Finland (earlier Finnish Game and Fisheries Research Institute), and partly originated from monitoring under the EU Data Collection Framework. The study was funded by Maj and Tor Nessling Foundation (Project 201700360) and Doctoral Programme in Environmental Physics, Health and Biology of the University of Eastern Finland as part of a thesis work of E.K. Christopher Elvidge is acknowledged for the grammatical revision of the manuscript. Two anonymous referees are acknowledged for their valuable advice.

Open Access This article is distributed under the terms of the Creative Commons Attribution 4.0 International License (http:// creativecommons.org/licenses/by/4.0/), which permits unrestricted use, distribution, and reproduction in any medium, provided you give appropriate credit to the original author(s) and the source, provide a link to the Creative Commons license, and indicate if changes were made.

\section{References}

Bergström, L., O. Heikinheimo, R. Svirgsden, E. Kruze, L. Ložys, A. Lappalainen, L. Saks, A. Minde, J. Dainys, E. Jakubavičiūtè, K. Ådjers \& J. Olsson, 2016. Long term changes in the status of coastal fish in the Baltic Sea. Estuarine, Coastal and Shelf Science 169: 74-84.

Beverton, R. J., \& S. J. Holt, 1957. On the dynamics of exploited fish populations, Fisheries Investigations (Series 2), volume 19. United Kingdom Ministry of Agriculture and Fisheries.

Bonsdorff, E., E. M. Blomqvist, J. Mattila \& A. Norkko, 1997. Coastal eutrophication: causes, consequences and perspectives in the archipelago areas of the Northern Baltic Sea. Estuarine, Coastal and Shelf Science 44(Supplement A): $63-72$.

Brännström, Å. \& J. J. T. Sumpter, 2005. The role of competition and clustering in population dynamics. Proceedings of the Royal Society of London, Series B. 272: 2065-2072.

Buijse, A. D. \& W. L. T. van Densen, 1992. Flexibility in the onset of piscivory and growth depensation in Eurasian perch. In In Buijse, A. D. (ed.), Perca fluviatilis L. Dynamics and exploitation of unstable percid populations. Wageningen Agricultural University, Wageningen: 89-121.

Böhling, P. \& H. Lehtonen, 1984. Effect of environmental factors on migrations of perch (Perca fluviatilis L.) tagged in the coastal waters of Finland. Finnish Fisheries Research 5: 31-40.

Böhling, P., R. Hudd, H. Lehtonen, P. Karås, E. Neuman \& G. Thoresson, 1991. Variations in year-class strength of different perch (Perca fluviatilis) populations in the Baltic Sea with special reference to temperature and pollution. Canadian Journal of Fisheries and Aquatic Sciences 48: 1181-1187.

Eklöv, P., 1997. Effects of habitat complexity and prey abundance on the spatial and temporal distributions of perch (Perca fluviatilis) and pike (Esox Lucius). Canadian Journal of Fisheries and Aquatic Sciences 54: 1520-1531.

Finnish Environment Institute, 2017. http://www.ymparisto.fi/ fi-FI/Luonto/Lajit/Lajien_seuranta/Merimetsoseuranta, Accessed July 30, 2018.

Hartman, K. J. \& F. J. Margraf, 1993. Evidence of predatory control of yellow perch (Perca flavescens) recruitment in Lake Erie, U.S.A. Journal of Fish Biology 43: 109-119.

Heikinheimo, O. \& H. Lehtonen, 2016. Overestimated effect of cormorant predation on fisheries catches: comment to the article by Salmi, J.A. et al., 2015: Perch (Perca fluviatilis) and pikeperch (Sander lucioperca) in the diet of the great cormorant (Phalacrocorax carbo) and effects on catches in the Archipelago Sea, Southwest coast of Finland. Fisheries Research, 164: 26-34. Fisheries Research 179: 354-357.

Heikinheimo, O., Z. Pekcan-Hekim \& J. Raitaniemi, 2014. Spawning stock-recruitment relationship in pikeperch Sander lucioperca (L.) in the Baltic Sea, with temperature as an environmental effect. Fisheries Research 155: 1-9.

Heikinheimo, O., P. Rusanen \& K. Korhonen, 2016. Estimating the mortality caused by great cormorant predation on fish stocks: pikeperch in the Archipelago Sea, northern Baltic Sea, as an example. Canadian Journal of Fisheries and Aquatic Sciences 73: 84-93.

Heikinheimo, O., H. Lehtonen, A. Lehikoinen, 2018. Comment to Hansson, S. et al. (2017): "Competition for the fish-fish extraction from the Baltic Sea by humans, aquatic mammals, and birds", with special reference to cormorants, perch, and pikeperch. ICES Journal of Marine Science 75(5): 1832-1836.

HELCOM 2018. Abundance of coastal fish key functional groups. HELCOM core indicator report. http://www. helcom.fi/baltic-sea-trends/indicators/abundance-of-coastalfish-key-functional-groups/. Accessed Sep 11, 2018.

Hilborn, R. \& C. J. Walters, 1992. Quantitative fisheries stock assessment: choice, dynamics and uncertainty. Chapman \& Hall, London.

Hjelm, J., L. Persson \& B. Christensen, 2000. Growth, morphological variation and ontogenetic niche shifts in perch (Perca fluviatilis) in relation to resource availability. Oecologia 122: 190-199.

Iles, T. C., 1994. A review of stock-recruitment relationships with reference to flatfish populations. Netherland Journal of Sea Research 32: 399-420.

Kallasvuo, M., J. Vanhatalo \& L. Veneranta, 2017. Modeling the spatial distribution of larval fish abundance provides essential information for management. Canadian Journal of Fisheries and Aquatic Sciences 74: 636-649.

Karås, P., 1987. Influences of larval mortality and first-year growth on the recruitment process of perch (Perca fluviatilis L.). In Kåras, P. (ed.), Food consumption, growth and 
recruitment in perch (Perca fluviatilis L.). Uppsala University, Uppsala.

Keskinen, T. \& T. J. Marjomäki, 2004. Diet and prey size spectrum of pikeperch in lakes in central Finland. Journal of Fish Biology 65: 1147-1153.

Keskinen, T. 2008. Feeding ecology and behaviour of pikeperch, Sander lucioperca (L.) in boreal lakes. In Keskinen, T. Jyväskylä studies in biological and environmental science 190: 30-38. https://jyx.jyu.fi/dspace/bitstream/ handle/123456789/18654/9789513932992.pdf?sequence $=$ 1

Kjellman, J., J. T. Lappalainen \& L. Urho, 2001. Influence of temperature on size and abundance dynamics of age 0 -group perch and pikeperch. Fisheries Research 53: $47-56$.

Kjellman, J., J. T. Lappalainen, L. Urho \& R. Hudd, 2003. Early determination of perch and pikeperch recruitment in the northern Baltic Sea. Hydrobiologia 495: 181-191.

Kuparinen, A., S. Kuikka \& J. Merilä, 2009. Estimating fisheries-induced selection: traditional gear selectivity research meets fisheries-induced evolution. Evolutionary Applications 2: 234-243.

Lappalainen, J., H. Lehtonen, P. Böhling \& V. Erm, 1996. Covariation in year-class strength of perch, Perca fluviatilis L. and pikeperch, Stizostedion lucioperca (L.). Annales Zoologi Fennici 33: 421-426. http://www.jstor. org/stable/23736085.

Lehikoinen, A., O. Heikinheimo \& A. Lappalainen, 2011. Temporal changes in the diet of great cormorant (Phalacrocorax carbo sinensis) — comparison with available fish data. Boreal Environment Research 16: 61-70.

Lehikoinen, A., O. Heikinheimo, H. Lehtonen \& P. Rusanen, 2017. The role of cormorants, fishing effort and temperature on the catches per unit effort of fisheries in Finnish coastal areas. Fisheries Research 190: 175-182.

Lehtonen, H., S. Hansson \& H. Winkler, 1996. Biology and exploitation of pikeperch, Stizostedion lucioperca (L.), in the Baltic Sea area. Annales Zoologi Fennici 33: 525-535. http://www.jstor.org/stable/23736098.

Leinonen, K. 1993. Vapaa-ajankalastuksen tilastointimenetelmät. In Kettunen, J., A. Laine, V. Karttunen, K. Leinonen, P. Mickwitz (eds) Kalatalous ajassa, vol. 11 (1993), Riista- ja kalatalouden tutkimuslaitos, SVT Ympäristö, Helsinki:125-128. (in Finnish).

Leinonen, K., P. Moilanen, J. Rinne, J. Stigzelius, A.-L. Toivonen, A.-L.Tuunainen \& R. Yrjölä, 1998. Kuinka Suomi kalastaa Osaraportti 2: Saaliit ja viehekalastusjärjestelmän käytännön toimivuus kalastusalueittain. Helsinki. Riista- ja kalatalouden tutkimuslaitos. Kala- ja riistaraportteja, vol. 131 (1998). (in Finnish)

Ljunggren, L., A. Sandström, U. Bergström, J. Mattila, A. Lappalainen, G. Johansson, G. Sundblad, M. Casini, O. Kaljuste \& B. Klemens Eriksson, 2010. Recruitment failure of coastal predatory fish in the Baltic Sea coincident with an offshore ecosystem regime shift. ICES Journal of Marine Science 67: 1587-1595.

Maceina, M. J. \& D. L. Pereira, 2007. Recruitment. In Guy, C. \& M. L. Brown (eds), Analysis and interpretation of freshwater fisheries data. American Fisheries Society, Bethesda, Maryland: 121-185.
Moilanen, P. 2001. Recreational fishing. In Kalatalous aikasarjoina - Finnish Fishery Time Series. Finnish Game and Fisheries Research Institute. SVT Agriculture, Forestry and Fishery, 60: 108-112.

Needle, C. L., 2001. Recruitment models: diagnosis and prognosis. Reviews in Fish Biology and Fisheries 11: 95-111.

Neuman, E., 1976. The growth and year-class strength of perch (Perca fluviatilis) in some Baltic archipelagoes, with special reference to temperature. Reports of the Institute of Freshwater Research 55: 51-70.

Neuman, E., E. Roseman \& H. Lehtonen, 1996. Determination of year-class strength in percid fishes. Annales Zoologi Fennici 33: 315-318. http://www.jstor.org/stable/ 23736073.

Ogle, D. H., 2015. Introductory Fisheries Analyses with R. Chapman \& Hall/CRC, Boca Raton, FL.

Olin, M., M. Rask, J. Ruuhijärvi, M. Kurkilahti, P. Ala-Opas \& O. Ylönen, 2002. Fish community structure in mesotrophic and eutrophic lakes of southern Finland: the relative abundances of percids and cyprinids along a trophic gradient. Journal of Fish Biology 60: 593-612.

Paxton, C. G., I. J. Winfield, J. M. Fletcher, D. G. George \& D. P. Hewitt, 2004. Biotic and abiotic influences on the recruitment of male perch in Windermere U.K. Journal of Fish Biology 65: 1622-1642.

Pekcan-Hekim, Z., L. Urho, H. Auvinen, O. Heikinheimo, J. Lappalainen, J. Raitaniemi \& P. Söderkultalahti, 2011. Climate warming and pikeperch year-class catches in the Baltic Sea. Ambio 40: 447-456.

Perälä, T. \& A. Kuparinen, 2017. Detection of Allee effects in marine fishes: analytical biases generated by data availability and model selection. Proceedings of the Royal Society B 284: 1-9.

Persson, L. \& A. Greenberg, 1990. Juvenile competitive bottlenecks: the perch (Perca fluviatilis)-roach (Rutilus rutilus) interaction. Ecology 71: 44-56.

Persson, L., K. Leonardsson, A. de Roos, M. Gyllenberg \& B. Christensen, 1998. Ontogenetic scaling of foraging rates and the dynamics of a size-structured consumer-resource model. Theoretical Population Biology 54: 270-293.

Persson, L., P. Byström \& E. Wahlström, 2000. Cannibalism and competition in Eurasian perch: population dynamics of an ontogenetic omnivore. Ecology 81: 1058-1071.

Pikitch, E. K., C. Santora, E. A. Babcock, A. Bakun, R. Bonfil, D. O. Conover, P. Dayton, P. Doukakis, D. Fluharty, B. Heneman, E. D. Houde, J. Link, P. A. Livingston, M. Mangel, M. K. McAllister, J. Pope \& K. J. Sainsbury, 2004. Ecosystem-based fishery management. Science 305: 346-347.

Punt, A. E., 1997. The performance of VPA-based management. Fisheries Research 29: 217-243.

Raitaniemi, J. \& O. Heikinheimo, 2018. Merialueen ahven. In Raitaniemi, J. (eds) Kalakantojen tila vuonna 2017 sekä ennuste vuosille 2018 ja 2019. Luonnonvara -ja biotalouden tutkimus 36/2018: 82-90. (In Finnish)

Ricker, W. E., 1954. Stock and recruitment. Journal of the Fisheries Research Board of Canada 11 (5): 559-623.

Rudstam, L. G., D. M. Green, J. L. Forney, D. L. Stang \& J. T. Evans, 1996. Evidence of interactions between walleye and yellow perch in New York State lakes. Annales 
Zoologici Fennici 33: 443-449. http://www.jstor.org/ stable/23736088.

Saila, S. B., C. W. Recksiek \& M. H. Prager (Eds) 1988. Basic fishery science programs. A Compendium of Microcomputer Programs and Manual of Operations. Developments in Aquaculture and Fisheries Science, 18. Elsevier, Amsterdam.

Salmi, J. A., H. Auvinen, J. Raitaniemi, M. Kurkilahti, J. Lilja \& R. Maikola, 2015. Perch (Perca fluviatilis) and pikeperch (Sander lucioperca) in the diet of the great cormorant (Phalacrocorax carbo) and effects on catches in the Archipelago Sea, Southwest coast of Finland. Fisheries Research 164: 26-34.

Schulze, T., U. Baade, H. Dörner, R. Eckmann, S. S. HaertelBorer, F. Hölker \& T. Mehner, 2006. Response of the residential piscivorous fish community to introduction of a new predator type in a mesotrophic lake. Canadian Journal of Fisheries and Aquatic Sciences 63: 2202-2212.

Seppänen, E., A.-L. Toivonen, M. Kurkilahti \& P. Moilanen, 2011. Suomi kalastaa 2009 - vapaa-ajankalastuksen saaliit kalastusalueittain. Finnish Game and Fisheries Research Institute, Tutkimuksia ja selvityksiä 7 (2011). (in Finnish)

Spiess, A.-N. \& N. Neumeyer, 2010. An evaluation of $\mathrm{R}^{2}$ as an inadequate measure for nonlinear models in pharmacological and biochemical research: a Monte Carlo approach. BMC Pharmacology 10: 1-11.

Szuwalski, C. S., K. A. Vert-Pre, A. E. Punt, T. A. Branch \& R. Hilborn, 2015. Examining common assumptions about recruitment: a meta-analysis of recruitment dynamics for worldwide marine fisheries. Fish and Fisheries 16: 633-648.

Toivonen, A.-L., P. Moilanen, J. Stigzelius \& E. Railo, 2002. Suomi kalastaa 2001 - Lajisaaliit. Helsinki Finnish Game and Fisheries Research Institute. Kala-ja riistaraportteja 283 (2002). (in Finnish)
Urho, L. 1996. Habitat shifts of perch larvae as survival strategy. Annales Zoologi Fennici 33: 329-340. http://www.jstor. org/stable/23736075.

Vainikka, A., E. Jakubavičiūtė \& P. Hyvärinen, 2017. Synchronous decline of three morphologically distinct whitefish (Coregonus lavaretus) stocks in Lake Oulujärvi with concurrent changes in the fish community. Fisheries Research 196: 34-46.

Vehanen, T., P. Hyvärinen \& A. Huusko, 1998. Food consumption and prey orientation of piscivorous brown trout (Salmo trutta) and pikeperch (Stizostedion lucioperca) in a large regulated lake. Journal of Applied Ichthyology 14: $15-22$.

Veneranta, L., L. Urho, A. Lappalainen \& M. Kallasvuo, 2011. Turbidity characterizes the reproduction areas of pikeperch (Sander lucioperca (L.)) in the northern Baltic Sea. Estuarine, Coastal and Shelf Science 95: 199-206.

Virtasalo, J., T. Kohonen, I. Vuorinen \& T. Huttula, 2005. Sea bottom anoxia in the Archipelago Sea, northern Baltic Sea-Implications for phosphorus remineralization at the sediment surface. Marine Geology 224: 103-122.

Zhang, F., K. B. Reid \& T. D. Nudds, 2017a. Relative effects of biotic and abiotic factors during early life history on recruitment dynamics: a case study. Canadian Journal of Fisheries and Aquatic Sciences 74: 1125-1134.

Zhang, F., K. B. Reid \& T. D. Nudds, 2017b. Ecosystem change and decadal variation in stock-recruitment relationships of Lake Erie yellow perch (Perca flavescens). ICES Journal of Marine Science 75: 531-540.

Publisher's Note Springer Nature remains neutral with regard to jurisdictional claims in published maps and institutional affiliations. 